\title{
Spatial association of mud volcano and sandstone intrusions, Boyadag anticline, western Turkmenistan
}

\begin{abstract}
AUTHORS
Davide Oppo $^{a *}$; Rossella Capozzi ${ }^{a}$

${ }^{a}$ Department of Biological, Geological and Environmental Sciences. University of Bologna, 40126 Bologna, Italy.

* Corresponding Author

Davide Oppo

Department of Biological, Geological and Environmental Sciences. University of Bologna, Via Zamboni 67, 40126 Bologna, Italy; davide.oppo2@unibo.it.
\end{abstract}

\section{RUNNING TITLE}

Sandstone intrusions-mud volcano, Turkmenistan

\section{ABSTRACT}

The mud volcano and sandstone intrusions complex occurring in the Boyadag anticline, western Turkmenistan, is the only well-documented example of co-existing, but not synchronous, mud volcanism and sand intrusion. Integrated field and laboratory evaluation investigates the spatial and genetic relations between the mud extrusion and the later sand intrusion. A sandstone dike and a pillar pierce mud volcano deposits on the crest of Boyadag anticline. Two more dikes occur near the escarpment caused by a crestal normal fault.

The rising of mud and hydrocarbons from the Oligocene Maykop Fm. fed the mud volcano after the exposure of the Lower Pleistocene units at the core of the anticline. The main 
physical process that later led to sand fluidization is identified as the progressive increase of pore fluid pressure, during a stage of reduced or null activity of the mud volcano, caused by the up-dip migration of hydrocarbons from the deep basin into the Pliocene sandstone reservoir within the Boyadag anticline. The hydrocarbons generated in the source rock levels of the Maykop Fm., whereas the saline water involved in the sand fluidization is identified as the connate water of the Pliocene Red Beds Fm. The pressure rise was responsible for the fracturing of the sealing units, already weakened by the crestal normal fault and the mud volcano feeding system. The sand intruded into sealing units and mud breccia deposits, also using the mud volcano conduit and the crestal normal fault as preferential pathways. During the present-day background activity, the outcropping sandstone intrusions provide high permeability pathways for continuous fluid leakage, precluding the re-establishment of high pressures in the reservoir. 


\section{INTRODUCTION}

The upward migration of buried mud and sand has been documented in numerous geological settings and sedimentary basins (e.g. Hovland et al., 1997; Milkov, 2000; Kopf, 2002; Hurst \& Cartwright, 2007; Ross et al., 2011). The stratigraphic and structural settings play a major role in controlling the their upward movement through the sedimentary column (e.g. Mazzini et al., 2009; Hurst et al., 2011; Capozzi et al., 2012). Moreover, the presence of fault systems generated by regional tectonics, or the formation of hydrofractures (Hurst et al., 2011), favour fluid and sediment migration (Hurst et al., 2003a; Schwartz et al., 2003; Vigorito et al., 2008; Capozzi et al., 2012). The understanding of fluid migration and sediment remobilization is helpful to define the evolution of sedimentary basins, in particular the history of the petroleum systems (e.g. Hurst \& Cartwright, 2007; Oppo et al., 2013). Sandstone intrusions may exert an important control in basins, being able to significantly modify pre-existing migration pathways; in addition they may form hydrocarbon traps (sandstone intrusive traps of Hurst et al., 2005). The association of mud volcanism and sand injection is rarely documented in literature. The only example of coupled sand extrusion and mud volcanism is described in the Gulf of Cadiz (Van Rensbergen et al., 2005). Sandstone intrusion and mud volcano complexes are reported only in western Turkmenistan by Kholodov (1987) and Oppo et al. (2014). Literature on sediment remobilization and fluid seepage occurring in the South Caspian Basin (SCB) region mainly refers to mud volcanism in the central and western zones of the basin (e.g. Davies \& Stewart, 2005; Mazzini et al., 2009), whereas Kholodov (2002) provides a general morphological description of related mud volcano and extruding sandstone diapirs occurring in the Boyadag anticline, western Turkmenistan. This paper analyses a unique case study of sand intrusion and mud volcano association, occurring in the Boyadag anticline, by investigating their spatial and genetic relations and defining the geological conditions responsible for sand fluidization. 


\section{GEOLOGICAL SETTING}

The South Caspian Basin encompasses the southern Caspian Sea and the coastal areas of eastern Azerbaijan, northern Iran and western Turkmenistan. The SCB is a deep intermountain sedimentary basin hosting a sediment pile up to $26-28 \mathrm{~km}$ thick (Brunet et al., 2003). The uplift and the subsequent erosion of the Caucasus, Elburz and Kopet-Dag ranges since the late Eocene caused high sedimentation rates, up to $4.5 \mathrm{~km} / \mathrm{My}$, in the whole basin (Smith-Rouch, 2006). The western Turkmenistan comprises the GograndagOkarem petroleum province (Smith-Rouch, 2006), where the Boyadag anticline is located (Fig. 1). In this area five sub-parallel anticline alignments are roughly oriented N-S, according with the regional stress field. The growth of these structures, which started in the late Pliocene (Lyberis \& Manby, 1999; Smith-Rouch, 2006), deformed the PlioPleistocene cover above deep Miocene thrust sheets that are possibly detached on Lower Miocene shales (Torres, 2007). To the north the structural axes are locally deflected towards the northeast due to the activity of the Ashgabat Wrench System, a Mesozoic extensional fault reactivated during the Neogene as right-lateral transpressive system (Berberian, 1983; Lyberis \& Manby, 1999).

Hydrocarbon generation is an important component of the SCB geology; they are extensively exploited and their migration is involved in the activity of numerous mud volcano structures (e.g. Etiope et al., 2004; Mazzini et al., 2009). The main hydrocarbon source rock in the Gograndag-Okarem petroleum province is the Oligocene Maykop Fm. (Torres, 2007) (Fig. 2). The generated thermogenic oil and gas migrate into the Pliocene Red Beds Fm., which is formed of ca. $2.5 \mathrm{~km}$ thick, cyclic fluvial-deltaic sandstonemudstone sequences deposited by the paleo Amu Darya river (Smith-Rouch, 2006). The deformation of Red Beds Fm. generated the structural traps that host the hydrocarbons in the region (Smith-Rouch, 2006) and that are sealed by Pliocene Akchagyl and Pleistocene 
Apsheron Fms. (Torres, 2007). The progressive charging of the reservoirs led to development of overpressures ranging from 1.25 to 1.75 times the hydrostatic pressure (Torres, 2007).

The mud volcanism in the SCB possibly started in the Early Miocene, and a Late Miocene-Early Pliocene strong Caspian Sea level drop represents the moment of maximum mud emission intensity in the basin (Huseynov \& Guliyev, 2004). The sediment sources can be as deep as $14 \mathrm{~km}$ (Cooper, 2001), as demonstrated by the Mesozoic and Paleogene rock fragments contained in the mud breccia discharged by the major mud volcanoes during paroxysmal events (Kholodov, 1987; Inan et al., 1997). However, the main source of mud feeding the volcanoes is located in the pelitic levels of the Maykop Formation (Kireeva \& Babaryan, 1985; Inan et al., 1997; Fowler et al., 2000; Planke et al., 2003). In the Gograndag-Okarem province, mud volcanoes frequently pierce the anticlines hosting hydrocarbon accumulations and allow the partial leakage of fluids (Fig. 1).

\section{DATA AND METHODS}

In the Boyadag anticline, the stratigraphic succession is well exposed, allowing field mapping and metre-scale lithostratigraphy observations. The tectonic setting has been reconstructed on the base of field observations and satellite images analysis. A geologic section crosscutting the anticline was reconstructed using data from the field survey. Samples of sandstone intrusions were collected to determine their characteristics and origin through optical microscope observation. Oil-filled sediment samples were collected to extract the hydrocarbon fraction and to analyse the oil biomarkers. Water samples have been analysed to determine their physical-chemical characteristics and ion abundances.

\section{RESULTS}

The Boyadag fluid emission and sediment remobilization complex 
The Boyadag complex is located on the western side of the Boyadag anticline and comprises different features linked with fluid emission and sediment remobilization (Fig. 3). The outcropping portion of the anticline is $100 \mathrm{~m}$ high, $20 \mathrm{~km}$ long and $4 \mathrm{~km}$ wide and has an E-W axis that plunges eastwards. The Boyadag anticline deforms the Pliocene Red Beds Fm. along with the Pliocene Akchagyl Fm., the Lower Pleistocene Apsheron Fm. and the Middle-Upper Pleistocene sedimentary succession. Important erosion exposed the Middle Pleistocene strata at the base of the anticline (Fig. 4a) and the Apsheron Fm. along the flanks and in the core. The Apsheron Fm. regionally consists of dominant mudstone interbedded with very thin sandstone layers (Torres, 2007) (Fig. 4b).. The regional unconformity marking the transition between the pelitic units of Akchagyl Fm. and the underlying sandy successions belonging to the Upper Red Beds Fm. is $800-1000$ m deep in the plain surrounding the Boyadag anticline (Auppov, 1968) and is ca. $400 \mathrm{~m}$ deep below the studied complex (Fig. 5).

The anticline is cut by numerous strike-slip faults (Fig. 3). A N-S trending crestal normal fault generates a depressed area that crosscuts the whole structure and the deformation induced by the fault throw creates a rollover anticline to the west (Figs. 3 and 5). This fault is marked by a steep escarpment at the base of which two sandstone dikes protrude through the Pleistocene pelitic sediments (Figs. 5, 6 and 7b). The dikes, the biggest of which is roughly $50 \mathrm{~m}$ long, $20 \mathrm{~m}$ high and $10 \mathrm{~m}$ thick, are composed of fine-grained quartzose sandstone with low pelitic matrix and cements. Deposits related to extruded sand do not occur in this area.

A 50 m-thick deposit of mud breccia occurs at the crest of the rollover anticline. This interval is composed of 1 to $10 \mathrm{~cm}$-thick mud flows (Figs. 7c and 8) with dispersed sandstone clasts (up to ca. $1 \mathrm{~cm}$ in diameter) and mudstone fragments. The mud breccia layers develop radially from a central point and downlap with an angle of $20^{\circ}$ to $30^{\circ}$ onto an erosional surface in the Apsheron Fm., below which strata dip $45^{\circ}$ to $60^{\circ}$ (Fig. $7 \mathrm{c}$ ). The 
occurrence of mud breccia interlayered in the Pleistocene succession has not been documented.

A pillar, 30-40 m high and 20-30 m in diameter, and a dike, $3 \mathrm{~m}$ high, $2 \mathrm{~m}$ thick and ca. $300 \mathrm{~m}$ long, protrude through the mud breccia deposits (Figs. 7a, c and Fig. 8). The two structures are formed of weakly cemented sandstone showing irregular flow-related morphologies, such as flow banding, which occur in the dike and at the rims of the pillar (Figs. 9a, b). Sandstone clasts in the internal part of the pillar, up to ca. $40-50 \mathrm{~cm}$ in diameter, in some cases showing fragmented sandstone pipe-like structures (Fig. 9c), are associated with few mudstone clasts $(5 \mathrm{~cm}$ to $10 \mathrm{~cm}$ in diameter). The sandstone is wellsorted and fine-grained, with prevalent sub-angular quartz grains, minor clastic limestone and mudstone, abundant pyrite and glauconite, rare mica and very weak calcareous cement. High contents of liquid hydrocarbons, along with native sulphur, were also observed within the sandstone.

Numerous small-scale features related to sediment remobilization and fluid leakage can be observed in the area comprised between the crest of the rollover anticline and the crestal normal fault. Inactive gryphons (Fig. 10a) have been observed in association with areas where the upper $30 \mathrm{~cm}$ of poorly consolidated sediments are impregnated with oil (Fig. 10b); in addition, clusters of sandy tar agglomerates were documented during the field survey (Fig. 10c). The leakage of fluids is still active in the Boyadag anticline. A circular structure that resembles a sinkhole, with ca. $5 \mathrm{~m}$ diameter and in which active emission of methane and saline water is observed, occurs in the centre of the depressed area (Fig. 11a). The present-day topography, which exposes the Pleistocene strata, leads to the constant discharge of high salinity water along the anticline limbs (Fig. 3) and from water springs observed near the gryphons (Fig. 11b).

\section{Brines}


The saline waters seeping near the gryphons and along the anticline limbs were sampled and analysed during the field survey for this work. Their analysis revealed that they have very similar compositions; therefore, a single sample is presented for simplicity.

The water is highly saline, in the range of brines (measured conductivity: $200 \mathrm{mS}$ ), has a slightly acid $\mathrm{pH}(6.46)$, reducing conditions (Eh: $-33.3 \mathrm{mV}$ ) and a temperature of $26{ }^{\circ} \mathrm{C}$ (Tab.1). The overall ionic composition shows the prevalence of chlorine, sodium and calcium, whose concentrations are strongly enriched with respect to both the Caspian Sea water and mean Sea Water (Tab. 1). Higher concentrations of ammonia (35.6 ppm), bromine (222 ppm), iodine (54 ppm), iron (4.531 ppm) and boron (55.22 ppm), compared to the mean Sea Water, are measured; magnesium does not vary significantly. The Boyadag water has extremely low bicarbonate ion concentrations (12.2 ppm), coupled with the total absence of sulphates.

\section{Hydrocarbons}

The oils extracted from two sediments samples collected near the gryphons are analysed. The analyses indicate a moderate level of biodegradation that led to the removal of most of the compounds with a low number of carbon atoms (Peters \& Moldowan, 1993). The moderate degree of degradation allows biomarker analysis, useful to determine the source rock characteristics and the thermal maturity of the oils.

The biomarkers indicating the lithology of the source rock, such as the $\mathrm{C}_{29}$ Hopanes/ $\mathrm{C}_{30}$ Hopanes ratio, the Diasterane ratio and the $\mathrm{Ts} / \mathrm{Ts}+\mathrm{Tm}$ ratio, have values of $0.48,0.44-0.41$ and 0.76 in the Boyadag 1 and 2 samples respectively (Tab. 2).

The typology of organic matter that generated the oil can be determined by analysing the regular steranes abundances (Moldowan et al., 1985; Philip et al., 1991), which show the prevalence of $\mathrm{C}_{28}$ (ca. $39.4 \%$ ) over $\mathrm{C}_{27}(30.05 \%$ to $32.7 \%)$ and $\mathrm{C}_{29}(27.88 \%$ to $30.52 \%)$. 
Oil maturity is determined calculating the equivalent vitrinite reflectance $\left(R_{c}\right)$ through the formula $\% R_{c}: 0.49(20 S / 20 R)+0.33$ (Gürgey, 2003), which resulted in the values of $0.75 \%$ and $0.70 \%$ for samples 1 and 2 , respectively (Tab. 2).

Another indicator of maturity is the $\mathrm{C}_{29}$ steranes isomerization from the $\alpha \alpha$ to $\beta \beta$ configuration in the $\mathrm{C}_{14}$ and $\mathrm{C}_{17}$ positions. This parameter reaches a stationary state around the peak oil generation with a value of 0.70 (Mackenzie et al., 1980). The values measured in Boyadag 1 and 2 samples are 0.52 and 0.46 , respectively. Both the equivalent vitrinite reflectance and the $\beta \beta /(\beta \beta+\alpha \alpha)$ sterane parameters evidence a slightly more elevated maturity in the Boyadag 1 with respect to the Boyadag 2 sample.

\section{DISCUSSION}

\section{Fluids origin}

\section{Brines}

Sand remobilization in the Boyadag anticline required the presence of significant volumes of overpressured pore water that acted as carrier for the sand during its migration. The understanding of physicochemical and geochemical characteristics of the brines that leak in the area gives information on their origin. The analysed brines have a temperature of $26{ }^{\circ} \mathrm{C}$, whereas the average annual temperature of the area is $17^{\circ} \mathrm{C}$ (Gürgey, 2003; Planke et al., 2003). The brine springs emit constant and relatively abundant volumes of water, therefore their temperature is not altered by that on surface and reflects the present thermal condition at ca. $500 \mathrm{~m}$ below the surface.

The origin of the chlorine occurring in the saline waters of sedimentary basins can be mainly ascribed to ambient waters at the time of sedimentation. In consequence of its conservative behaviour, the variation of $\mathrm{Cl}$ is mainly due to diffusion and filtration mechanisms, and not to the thermodynamic equilibrium with one or more mineral phases (Hanor, 1994). Cl-bearing evaporites have not been documented so far in the Neogene 
succession of the Gograndag-Okarem province. However, the occurrence of thin anhydrite layers (up to $1 \mathrm{~m}$ ) in the Red Beds Fm. (Torres, 2007) suggests the possible presence of other evaporites and, thus, a partial input of $\mathrm{Cl}$ derived from their dissolution cannot be completely ruled out.

In general, the diagenetic evolution also leads to an increase of calcium concentrations with depth, coupled with the progressive decrease of magnesium in solution (Hanor, 1994, 2001; Kharaka \& Hanor, 2003). Carbonate precipitation/dissolution appears to have a negligible role in regulating the amount of $\mathrm{Ca}$ present in the Boyadag water, due to the very scarce occurrence of carbonate units (Torres, 2007), apart from minor limestone clasts in the sandstone layers. Therefore, the abundances of $\mathrm{Ca}$ and $\mathrm{Mg}$ can be mainly influenced by the interaction with silicate minerals. The process of smectite dissolution and illite precipitation is extremely important in many sedimentary basins, including the SCB (e.g. Buryakovsky et al., 1995; Planke et al., 2003). The onset of this temperature-related transformation is at $60^{\circ} \mathrm{C}$ (e.g. Nadeau, 2011), located ca. $2.5 \mathrm{~km}$ deep in the SCB. The transition between the Lower and the Upper Red Beds Fm. has been found around this depth in the Gograndag-Okarem province; this is the transition from thin-bedded very finegrained sandstone and shale units, to the fine to medium sandstone beds, 5 to10 m thick, which are the exploration target in the eastern South Caspian Basin (Torres, 2007). According to the mechanism illustrated by Kharaka \& Hanor (2003), the water and solutes released and adsorbed during smectite to illite transformation are one of the dominant factors in regulating the pore water geochemistry. This process could be responsible for the release of large amounts of calcium, sodium and iron in the interstitial water. Moreover, according to the theory proposed by Hanor (1994), a gradual mobilization of quartz is observed. The silica derived from quartz crystals and from anorthite hydrolysis, which in turn releases calcium ions in solution, contributes to the formation of clay minerals and quartz. Quartz solubility increases in solutions with high chlorine content (Hanor, 1994). 
The measured $\mathrm{SiO}_{2}$ content in the brines $\left(10.5 \mathrm{ppm}\right.$ at $\left.26^{\circ} \mathrm{C}\right)$ is close to the real solubility of quartz in this system, also considering that the saturation condition in pure water at $25^{\circ} \mathrm{C}$ is $6 \mathrm{ppm}$ (Morey et al., 1962). The increase in Ca could result from processes of plagioclase albitization, with associated decrease of $\mathrm{Na}$ in solution. Additionally, carbonate precipitation is inhibited by the observed undersaturation condition, favouring the preservation of significant amounts of calcium in solution. The undersaturation condition for carbonates is also provided by the observed activity of acid-producing bacteria (APB). The decrease of magnesium, then, is not linked to carbonate precipitation and may result from its inclusion in the crystal lattice of the mica crystals and by the adsorption on clay minerals (Kharaka \& Hanor, 2003).

The removal of $\mathrm{SO}_{4}$ from solution could be attributed to reduction processes controlled by sulphate-reducing bacteria (SRB) and to precipitation in mineral phases. However, in the brines the SRB are absent and this condition is related to the temperature of $26^{\circ} \mathrm{C}$, which does not presently allow the SRB activity and, consequently, the bicarbonate associated to sulphate reduction is very low. The precipitation of sulphur and/or gypsum within the sedimentary sequence has been documented in various Turkmenistan mud volcanoes (Huseynov \& Guliyev, 2004) and significant amounts of sulphur were observed near the sandstone dikes on the crest of the Boyadag rollover anticline. Moreover, the sandstone forming the dikes and pillar has very low amounts of carbonate cements, due to the undersaturation of carbonates in the waters.

The $\delta^{18} \mathrm{O}$ and $\delta \mathrm{D}$ stable isotopes in the Boyadag water (Tab. 1) are similar to the typical values of the reservoir waters in the Gograndag-Okarem region (Fig. 12). Boron concentration could provide a further indication of the water origin. With the temperature increase resulting from the progressive burial, $B$ is released from the clay due to dehydration processes and increases in the waters. According to the model proposed by Kopf \& Deyhle (2002) for worldwide mud volcano waters, the value of dissolved boron in 
the Boyadag water (55.22 ppm) suggests that its main source is ca. $2-3 \mathrm{~km}$ deep. This depth matches the one estimated regionally for the Red Beds successions (Fig. 2). The chemical composition of the water leaking in the Boyadag anticline indicates that it originates at depth from the mudstone layers in the Lower Pliocene units and subsequently migrates towards the anticline along the overlying sandstone intervals.

\section{Hydrocarbons}

The two samples show similar characteristics and are therefore considered subsamples of the same oil. The lithology of the source rock and the characteristics of the organic matter are fundamental to identify the units of the sedimentary succession that generated the hydrocarbon contained in the reservoirs. The source rock that generated the oil in the Boyadag area is mainly clayey, as indicated by the low $\mathrm{C}_{29}$ Hopanes $/ \mathrm{C}_{30}$ Hopanes ratio (Tab. 2) (Palacas et al., 1984) and confirmed by the Diasterane ratio and by the high Ts/Ts+Tm ratio (Gürgey, 2003).

The Boyadag oil shows the dominance of $\mathrm{C}_{28}$ over $\mathrm{C}_{27}$ and $\mathrm{C}_{29}$ steranes, representative of an origin from sediments deposited in a marine environment. The $\mathrm{C}_{27}$ and $\mathrm{C}_{28}$ regular steranes are more abundant in marine organic matter, whereas the $\mathrm{C}_{29}$ steranes originate

from higher plants and some primitive algae and cyanobacteria (Peters \& Moldowan, 1993; Volkman et al., 1999).

The calculated equivalent vitrinite reflectance $(0.75 \%$ and $0.70 \%)$ indicates that the oil has been generated by a source rock during the initial peak of oil generation. Another parameter that can be used to assess the oil maturity is the $\mathrm{C}_{29}$ steranes isomerization from the $\alpha \alpha$ to $\beta \beta$ configuration. Also in this case the values indicate moderately mature oil. The depth of oil generation could be calculated on the base of its maturity level. Considering the low thermal gradient in the SCB of about $17^{\circ} \mathrm{C} / \mathrm{km}$ (Diaconescu et al., 2001 and references therein), the mean atmospheric temperature of $17^{\circ} \mathrm{C}$ (Gürgey, 2003; 
Planke et al., 2003) and given the oil maturity level, corresponding to temperatures in the $100 / 110^{\circ} \mathrm{C}$ range, the oil has been generated approximately 4.8 to $5.4 \mathrm{~km}$ at depth. The biomarker analysis and the determined source rock maturity suggest that the Boyadag oil was generated by the productive intervals of the Maykop Fm., whose depth in the area is compatible with the estimated range (Fig. 2).

\section{The evolution of the Boyadag fluid emission and sediment remobilization complex}

During the Neogene, the compressional tectonics acting in western Turkmenistan formed the anticline structural traps, which were filled by hydrocarbons and that presently show overpressure conditions (Torres, 2007). Local seal disruption favoured the upward migration of deep mud and fluids, generating mud volcano structures; this process is recognized as the main cause of mud volcanism in the Gograndag-Okarem province (Torres, 2007).

The depositional geometries of the mud breccia flows occurring on the crest of the Boyadag rollover anticline indicate that this interval was deposited by the activity of a mud volcano, now inactive (Fig. 13a). The progressive erosion of the mud breccia exposed the sandstone pillar located at the centre of the radial mud breccia flows that, thus, marks the main feeding conduit of the mud volcano (Figs. 8 and 13d). The sandstone pierce the mud volcano edifice and extrudite deposits are not observed in the mud breccia; therefore, mud extrusion predates sandstone emplacement and makes mud volcanism the first episode of sediment remobilization in the Boyadag anticline.

The emplacement of the mud volcano on the eroded top of the rollover anticline and the absence of mud breccia interlayers in the Apsheron Fm. units constrain the activity of the mud volcano to after their deformation and partial erosion. Present day active mud emission has not been observed in the field and the time at which it ceased cannot be defined. The time required for eroding the volcano edifice and exposing the sandstone is 
clearly much more than would be necessary to erode the small gryphons occurring in the depressed area (Fig. 10a). Therefore, their presence attests minor episodes of mud emission in recent times, after the end of the main mud volcano activity. The expulsion of the sandy tar agglomerates (Fig. 10c), along with gas and brine emission near the small mud cones (Fig. 10b), testifies the leakage of important amounts of hydrocarbons. Moreover, the low biodegradation level of the oils indicates that they have not been exposed to a biodegrading environment for long time. The gryphons, the structure resembling a sinkhole and the brine springs in the depressed area indicate that the fluids are actively circulating in the anticline subsurface, likely through a complex network of faults, fractures and/or pipe-like discontinuities.

The morphology of sandstone dikes and pillar (Fig. 9a, b) suggests vertical flow of unconsolidated sand from the underlying sedimentary succession and their intrusion up into the overlying pelitic units. Exploration wells in the Gograndag-Okarem province revealed that the sandstone intervals of the Upper Red Beds Fm. are composed of finegrained sandstones with abundant quartz grains and minor mica, pyrite, intraformational mudstone clasts and minor carbonate cements (Torres, 2007). These characteristics match what we could observe on the outcropping sandstone petrography. Therefore, the sandy levels of the Pliocene Upper Red Beds Fm. are the most suitable units that could have acted as sediment parent layers for the intrusions.

The post-depositional remobilization of sand bodies has been widely analysed (e.g. Hurst et al., 2011). The sand injection process requires the establishment of suitable conditions in the parent layers to generate a rapid fluid flow and a prerequisite is overpressure of the pore fluids. Therefore, the presence of sandstone intrusions in the Boyadag anticline implies that the parent sandstone sealed at depth became overpressured prior to injection. Differential overloading due to the growth of Boyadag anticline, the progressive input of hydrocarbons migrating from the Maykop Fm. and the generation of biogenic methane 
from the Pliocene organic matter should be accounted for the development of the elevated overpressures. .

The role of mud volcanoes for degassing deeply buried sediments is recognised, as is the alternation of mud emission and quiescent phases during their activity (e.g. Dimitrov, 2002). The Boyadag mud volcano was able to partially degas the reservoir units; however when the mud volcano experienced a quiescence phase, or even the end of its activity, the emission of hydrocarbons ceased, leading to their accumulation and, thus, to the progressive pressure rise (Fig. 13b). This overpressure regime ultimately exceeded the hydrofracturing gradient of the sealing pelitic Akchagyl and Apsheron Fms. (e.g. Clayton \& Hay, 1994) and triggered sand fluidization (Fig. 13c).

During the sand rising, hydrocarbon gas is released from the solution, increasing the Pliocene connate water flow velocity and thereby enhancing sand entrainment ability (Huuse et al., 2010). The sandstone intrusions exploited the N-S crestal normal fault and the mud volcano feeding conduit, as demonstrated by their spatial association; also, a system of hydrofractures generated by the overpressure in the reservoir is evidenced by the occurrence of the radial sandstone dike near the pillar. The crestal normal fault that was involved during the fluid and sediment migration, located in the western axial culmination of the Boyadag anticline, formed as a consequence of the regional deformation stress field acting along a NNE-SSW direction. The formation of similar crestal normal faults has been discussed in Morley (2007). After the end of the migration, the sand intrusion was responsible for the infilling of the mud volcano conduit.

The role of sandstone intrusions in enhancing the vertical permeability and favouring hydrocarbons migration in petroleum basins has been documented (Hurst et al., 2003b). Thin sections observations show that the intruded sandstones are weakly cemented and the porosity and permeability are high. The intrusions connect the reservoir to the surface piercing the seal units and, thus, favouring the upward migration of fluids (Fig. 13d). This 
process prevents the re-establishment of overpressure conditions at depth. Consequently, the occurrence of important fluid emission events is inhibited and only minor seepage activity is recorded nowadays.

Despite of overpressure occurs in numerous structural traps in western Turkmenistan (Torres, 2007), most of the related anticlines do not show exposed sandstone intrusions or extrusions. The only other known spatially associated mud volcano and sandstone intrusion is documented at the Alakel mud volcano, northwestern Turkmenistan (Oppo et al., 2014). The intrusions are formed of weakly cemented, oil-saturated sandstones interpreted to originate from the Red Beds Fm. and have morphologies comparable with the dikes in the Boyadag anticline (Fig. 5a in Oppo et al., 2014). Alakel presents some characteristics similar to the Boyadag complex, such as the occurrence of a presently inactive mud volcano crosscut by various normal faults. It can be hypothesised that the fluids circulation system of the mud volcano and the normal faults favour the sand intrusion through the rupture of seal units.

\section{CONCLUSIONS}

This paper for the first time presents a detailed analysis of the spatial association between mud volcano and sand intrusion features, through the study of the structures occurring in the Boyadag anticline, western Turkmenistan. The Boyadag sandstone intrusions and mud volcano complex allows to study the relations between tectonic deformation, reservoir formation, fluid migration and sediment remobilization. Moreover, it allows adding information on the process leading to intrusions emplacement.

The Boyadag anticline has been generated by the regional compressive tectonics deforming the Plio-Pleistocene sediments of the Gograndag-Okarem Petroleum Province, and is cut by strike-slip and normal faults. The anticline generated a structural trap fed by active migration of hydrocarbons, which partially leak to the surface. The hydrocarbons 
were generated in the productive levels of the Maykop Fm. and subsequently migrated up to the reservoir sandstone. Mud breccia, deposited radially from a central vent on the crest of the Boyadag rollover anticline, testifies the past occurrence of a mud volcano that was active in recent times, at least during the late Pleistocene. During a stage of reduced or null activity of the mud volcano, the pressure in the reservoir sandstone rose progressively above the level of the fracturing gradient because of focused upward-migration of fluids and lack of their discharge to the surface by the mud volcano. This pressure build-up led to the fracture of sealing units and the subsequent rapid pressure release, causing the fluidization of the sand in the reservoir. The saline water necessary for sand fluidization originated from the pore water contained in the Red Beds Fm. The remobilized sand partially intruded along discontinuities, such as the crestal normal fault and the mud volcano conduit, leading to the infilling of this latter. The definitive end of the mud volcano activity could be ascribed to the reservoir degassing through the sandstone intrusions. The occurrence of the sandstone dike near the pillar testifies that the intrusion was able to generate radial hydrofracturing during the migration along the volcano conduit. The high permeability of the sand intrusions and the present day seepages are responsible for the continuous expulsion of fluids, precluding the re-establishment of high pressures in the reservoir.

\section{ACKNOWLEDGMENTS}

The Authors are indebted with Dr. Barbara Cerasetti, scientific coordinator of the Italian Archaeological Program in Turkmenistan (Dipartimento di Storia, Culture, Civiltà Università di Bologna - Ministero per gli Affari Esteri - MAE), for the logistical help before and during the field activities in Turkmenistan. Our thanks to the administration of the 
National Institute of Deserts, Flora and Fauna, to the Turkmenistan Government and to Dr. Aman Nigarov for the fruitful assistance in the field. We want to thank Prof. Marco Antonellini for the discussions on sandstone intrusions. The authors are indebted to the reviewers J. Peakall, P. Imbert, A. Hurst and an anonymous reviewer for the very helpful comments to the manuscript. Funding was provided by Prof. G. Gabbianelli for the field survey and by PRIN 2009 grants to Prof. Rossella Capozzi.

\section{CONFLICT OF INTEREST}

No conflict of interest declared

\section{REFERENCES}

ABRAMS, M. \& NARIMANOV, A. (1997) Geochemical evaluation of hydrocarbons and their potential sources in the western South Caspian depression, Republic of Azerbaijan. Marine and Petroleum Geology, 14, 451-468.

AUPPOV H.P. (1968) Geological Map of Turkmen CCP, CCCP Ministry of Geology, Moscow.

BERBERIAN, M. (1983). The southern Caspian: a compressional depression floored by a trapped, modified oceanic crust. Canadian Journal of Earth Sciences, 20, 163-183.

BRUNET, M., KOROTAEV, M., ERSHOV, A. \& NIKISHIN, A. (2003) The South Caspian Basin: A review of its evolution from subsidence modeling. Sedimentary Geology, 156, $119-148$.

BURYAKOVSKY, L., DJEVANSHIR, R. \& CHILINGAR, G. (1995) Abnormally-high formation pressures in Azerbaijan and the South Caspian Basin (as related to smectite 
illite transformations during diagenesis and catagenesis). Journal of Petroleum Science and Engineering, 13, 203-218.

CAPOZZI, R., ARTONI, A., TORELLI, L., LORENZINI, S., OPPO, D., MUSSONI, P. \& POLONIA, A. (2012). Neogene to Quaternary tectonics and mud diapirism in the Gulf of Squillace (Crotone-Spartivento Basin, Calabrian Arc, Italy). Marine and Petroleum Geology, $35,219-234$.

CLAYTON, C.J. \& HAY, S.J. (1994) Gas migration mechanisms from accumulation to surface. Bulletin of the Geological Society of Denmar 41, 12-23.

COLLINS, A.G. (1975) Geochemistry of oilfield waters. Development in petroleum science 1, Elsevier, Amsterdam.

COOPER, C. (2001) Mud volcanoes of Azerbaijan visualized using 3D seismic depth cubes: the importance of overpressured fluid and gas instead of non extant diapirs. In: Abstracts Volume Subsurface Sediment Mobilization Conference, p. 71, 10-13 September, Ghent, Belgium.

DAVIES, R. \& STEWART, S. (2005) Emplacement of giant mud volcanoes in the South Caspian Basin: 3D seismic reflection imaging of their root zones. Journal of the Geological Society, 162, 1-4.

DIACONESCU, C.C., KIECKHEFER, R.M. \& KNAPP, J.H. (2001) Geophysical evidence for gas hydrates in the deep water of the South Caspian Basin, Azerbaijan. Marine and Petroleum Geology, 18, 209-221.

DIMITROV, L., (2002) Mud volcanoes--the most important pathway for degassing deeply buried sediments. Earth Science Reviews, 59, 49-76. 
ETIOPE, G., FEYZULLAYEV, A., BACIU, C. \& MILKOV, A. (2004) Methane emission from mud volcanoes in eastern Azerbaijan. Geology, 32, 465-468.

FOWLER, S., MILDENHALL, J., ZALOVA, S., RILEY, G., ELSLEY, G., DESPLANQUES, A. \& GULIYEV, F. (2000) Mud volcanoes and structural development on Shah Deniz. Journal of Petroleum Science and Engineering, 28, 189-206.

GÜRGEY, K. (2003) Correlation, alteration, and origin of hydrocarbons in the GCA, Bahar, and Gum Adasi fields, western South Caspian Basin: geochemical and multivariate statistical assessments. Marine and Petroleum Geology, 20, 1119-1139.

HANOR, J.S. (1994) Origin of saline fluids in sedimentary basins. In: Geofluids: Origin, Migration and Evolution of Fluids in Sedimentary Basins (Ed. by Parnell, J.), Geological Society London Special Publications, 78, 151-174.

HANOR, J.S. (2001) Reactive transport involving rock-buffered fluids of varying salinity. Geochimica et Cosmochimica Acta, 65, 3721-3732.

HOVLAND, M., HILL, A. \& STOKES, D. (1997) The structure and geomorphology of the Dashgil mud volcano, Azerbaijan. Geomorphology, 21, 1-15.

HURST, A., CARTWRIGHT, J.A. \& DURANTI, D. (2003a) Fluidization structures produced by upward injection of sand through a sealing lithology. In: Subsurface Sediment Mobilization (Ed. by Van Rensbergen, P., Hillis, R.R., Maltman, A.J., Morley, C.K.), Geological Society Special Publication, 216, 123-137.

HURST, A., CARTWRIGHT, J.A., HUUSE, M., JONK, R., SCHWAB, D., DURANTI \& D., CRONIN, B. (2003b) Significance of large-scale sand injectites as long term fluid conduits: evidence from seismic data. Geofluids, 3, 263-274.

HURST, A., CARTWRIGHT, J.A., DURANTI, D., HUUSE, M. \& NELSON, M. (2005) Sand 
injectites: an emerging global play in deep-water clastic environments. In: Petroleum Geology: North-west Europe and Global Perspectives (Ed. by Doré, A. \& Vining, B.), Proceedings of the 6th Petroleum Geology conference. Geological Society, London, 133144.

HURST, A. \& CARTWRIGHT, J., (Eds.) (2007) Sand Injectites: Implication for hydrocarbon exploration and Production. AAPG Memoir 87, Tulsa, USA.

HURST, A., SCOTT, A. \& VIGORITO, M. (2011) Physical characteristics of sand injectites. Earth Science Reviews, 106, 215-246.

HUSEYNOV, D.A. \& GULIYEV, I.S. (2004) Mud volcanic natural phenomena in the South Caspian Basin: geology, fluid dynamics and environmental impact. Environmental Geology, $46,1012-1023$.

HUUSE, M., JACKSON, C.A.-L., VAN RENSBERGEN, P., DAVIES, R.J., FLEMINGS, P.B. \& DIXON, R.J. (2010) Subsurface sediment remobilization and fluid flow in sedimentary basins: an overview. Basin Research, 22, 342-360.

INAN, S., NAMIK YALCIN, M., GULIEV, I., KULIEV, K. \& FEIZULLAYEV, A. (1997) Deep petroleum occurrences in the Lower Kura Depression, South Caspian Basin, Azerbaijan: an organic geochemical and basin modeling study. Marine and Petroleum Geology 14, $731-762$.

JACKSON, J., PRIESTLEY, K, ALLEN, M. \& BERBERIAN, M. (2002) Active tectonic of the South Caspian Basin. Geophysical Journal International 148, 214-245.

JOLLY, R. \& LONERGAN, L., 2002. Mechanisms and controls on the formation of sand intrusions. Journal of the Geological Society, 159, 605-617. 
KHARAKA, Y.K. \& HANOR, J.S. (2003) Deep fluids in the continents: I. Sedimentary basins. Treatise on geochemistry 5, 499-540.

KHOLODOV, V. (1987) The Role of Sand Diapirism in the Genesis of Mud Volcanoes. Litol. Polezn. Iskop., 4, 12-28. (in Russian).

KHOLODOV, V. (2002) Mud volcanoes, their distribution regularities and genesis: communication 1. Mud volcanic provinces and morphology of mud volcanoes. Lithology and Mineral Resources, 37, 197-209.

KIREEVA L. \& BABAYAN D. (1985) Genetic analysis of oil and gas accumulations of Middle Pliocene deposits of southwestern Turkmenistan. Geologiya e naftegazonosnost Turkmenistana, Ylym Publisher House, Ashgabat, Turkmenistan (in Russian).

KOPF, A. \& DEYHLE, A. (2002) Back to the roots: boron geochemistry of mud volcanoes and its implications for mobilization depth and global B cycling. Chemical Geology, 192, 195-210.

LYBERIS, N. \& MANBY, G. (1999) Oblique to orthogonal convergence across the Turan block in the post-Miocene. AAPG Bulletin, 83, 1135-1160.

LAVRUSHIN, V., DUBININA, E. \& AVDEENKO, A., 2005 Isotopic composition of oxygen and hydrogen in mud-volcanic waters from Taman (Russia) and Kakhetia (Eastern Georgia). Lithology and Mineral Resources 40, 123-137.

MACKENZIE, A., PATIENCE, R. \& MAXWELL, J. (1980) Molecular parameters of maturation in the Toarcian shales, Paris Basin, France $-I$. Changes in the configurations of acyclic isoprenoid alkanes, steranes and triterpanes. Geochimica et Cosmochimica Acta, 44, 1709-1721. 
MAZZINI, A., SVENSEN, H., PLANKE, S., GULIYEV, I., AKHMANOV, G.G., FALLIK, T. \& BANKS, D. (2009) When mud volcanoes sleep: Insight from seep geochemistry at the Dashgil mud volcano, Azerbaijan. Marine and Petroleum Geology, 26, 1704-1715.

MILKOV, A. (2000) Worldwide distribution of submarine mud volcanoes and associated gas hydrates. Marine Geology, 167, 29-42.

MOLDOWAN, J.M., SEIFERT, W.K. \& GALLEGOS, E.J. (1985) Relationship between petroleum composition and depositional environment of petroleum source rocks. AAPG Bulletin, 69, 1255-1268.

MOREY, G.W, FOURNIER \& R.O, ROWE, J.J. (1962) The solubility of quartz in water in the temperature interval from $25^{\circ}$ to $300^{\circ} \mathrm{C}$, Geochimica et Cosmochimica Acta, 26, 10291040.

Morley, C.K. (2007) Development of crestal normal faults associated with deepwater fold growth. Journal of Structural Geology, 29, 1148-1163.

NADEAU, P.H., (2011) Earth's energy 'Golden Zone': a synthesis from mineralogical research. Clay Minerals, 46, 1-24.

OPPO, D., CAPOZZI R., NIGAROV, A. \& PALTAMET, E. (2014) Mud volcanism and fluid geochemistry in the Cheleken Peninsula, western Turkmenistan. Marine and Petroleum Geology, 57, 122-134.

OPPO, D., CAPOZZI, R. \& PICOTTI, V. (2013) A new model of the petroleum system in the Northern Apennines, Italy. Marine and Petroleum Geology, 48, 57-76.

PALACAS, G.P., ANDERS, D.E. \& KING, J.D. (1984) South Florida Basin-A prime example of carbonate source rocks of petroleum In: Petroleum Geochemistry and Source 
Rock Potential of Carbonate Rocks (Ed. by Palacas, G.P.), AAPG Studies in geology, 18, 71-96.

PETERS, K.E. \& MOLDOWAN, J.M. (1993) The biomarker guide: Interpreting molecular fossils in petroleum and ancient sediments, Prentice Hall, Englewood Cliffs, NJ (USA).

PHILIP, R.P., FAN, P., LEWIS, C.A., LI J., ZHU, H. \& WANG, H. (1991) Geochemical characteristics of oils from Chaidamu, Shanganning and Jianghan basins, China. Journal of Southeast Asian Earth Science, 5, 351-358.

PLANKE, S., SVENSEN, H., HOVLAND, M., BANKS, D.A. \& JAMTVEIT, B. (2003) Mud and fluid migration in active mud volcanoes in Azerbaijan. Geo-Mar Lett, 23, 258-268.

ROSS, J.A., PEAKALL, J. \& KEEVIL, G.M. (2011) An integrated model of extrusive sand injectites in cohesionless sediments. Sedimentology, 58, 1693-1715.

SCHWARTZ, H., SAMPLE, J., WEBERLING, K.D., MINISINI, D. \& MOORE, J.C. (2003) An ancient linked fluid migration system: cold-seep deposits and sandstone intrusions in the Panoche Hills, California, USA. Geo-Mar Lett., 23, 340-350.

SMITH-ROUCH, L.S. (2006) Oligocene-Miocene Maykop/Diatom Total Petroleum System of the South Caspian Basin Province, Azerbaijan, Iran, and Turkmenistan. U.S. Geological Survey Bulletin, 2201-I.

TORRES, M.A. (2007) The petroleum geology of Western Turkmenistan: the GograndagOkarem province. In: Oil and Gas of the Greater Caspian area (Ed. by Yilmaz, P.O. \& Isaksen, G.H.), AAPG Studies in Geology, 55, 109-132.

VAN RENSBERGEN, P., DEPREITER, D., PANNEMANS, B. \& HENRIET, J.-P. (2005) Seafloor expression of sediment extrusion and intrusion at the El Arraiche mud volcano field, Gulf of Cadiz. Journal of Geophysical Research, 110, F02010. 
VIGORITO, M., HURST, A., CARTWRIGHT, J. \& SCOTT, A. (2008) Regional-scale subsurface sand remobilization: geometry and architecture. Journal of the Geological Society, 165, 609-612.

VIGORITO, M. \& HURST, A. (2010) Regional sand injectite architecture as a record of pore-pressure evolution and sand redistribution in the shallow crust: insights from the Panoche Giant Injection Complex, California. Journal of the Geological Society of London, 167, 889-904.

VOLKMAN, J., BARRETT, S. \& BLACKBURN, S.I. (1999) Eustigmatophyte microalgae are potential sources of C29 sterols, C22-C28 n-alcohols and C28-C32 n-alkyl diols in freshwater environments. Organic Geochemistry, 30, 307-318. 


\section{FIGURES AND TABLES CAPTIONS}

Fig. 1 Map of western Turkmenistan. Major oil and gas fields are located in correspondence of anticline alignments and are often associated with mud volcanoes, both active and extinct, which pierce the reservoir and seal units. The Boyadag anticline is located (Modified from Oppo et al., 2014).

Fig. 2 Stratigraphic column of the Gograndag-Okarem petroleum province. The average thickness of units is indicated. The sandstone reservoirs, pertaining to the Pliocene Red Beds, are ca. $1500 \mathrm{~m}$ thick (Modified from Torres, 2007).

Fig. 3 Western Boyadag anticline. The sandstone intrusions protrude from the mud breccia deposits and along the N-S trending crestal normal fault plane. Small strike-slip faults dissect the outcropping Pleistocene strata along the anticline limbs. The location of other emission-related structures is evidenced. Various springs of high saline water occur. The trace of section A-A' (Fig. 5) is shown. (Satellite image from Google Earth).

Fig. 4 a) Middle Pleistocene succession outcropping at the base of the anticline, formed by the alternation of pelitic sediments and sandstone layers, ca. $2-3 \mathrm{~cm}$ thick, with currentproduced bed forms. The strata dip ca. $45^{\circ} \mathrm{W}$. b) Lower Pleistocene mudstone with very thin sandstone interlayers, pertaining to the Apsheron Fm., outcropping along the anticline flanks.

Fig. 5 Cross-section along the anticline major axis, showing the relations between the sandstone intrusions, the mud breccia deposits and the crestal normal fault. The dotted yellow strata represent the regionally extended Pliocene sandstone reservoirs, the white areas are mudstone seal units. The fluids migrate up-dip from the sediments located in the subsurface of the Boyadag region. 
Fig. 6 Panoramic view of the Boyadag rollover anticline, oriented as the cross section of Fig. 5. The sandstone intrusions and the mud breccia deposits are evidenced.

Fig. 7 a) Sandstone dike outcropping on the crest of the rollover anticline and extending radially from the pillar. b) Sandstone dikes located in correspondence of the crestal normal fault. c) Erosional unconformity (red line) at the transition between the folded Lower Pleistocene strata and thin-layered mud breccia. The mud breccia outcropping in foreground is ca. $4 \mathrm{~m}$ thick; the pillar in background ca. $40 \mathrm{~m}$ high.

Fig. 8 Detail of the mud breccia at the base of the pillar structure. White arrows point to particularly thick mud breccia layers. Note the sandstone boulders due to the pillar erosion. People for scale.

Fig. 9 The sandstone dikes (a) and the external zone of pillar (b) show vertical flow-related morphologies. c) Sandstone clasts included in the internal portions of pillar. A fragment of pipe-like structure can be seen (arrow).

Fig. $10 \quad$ a) Inactive mud gryphon occurring in the depressed area (diameter circa 1 m). b) The sediment surrounding the gryphons contains high amounts of oil. c) Cluster of sandy tar aggregates (up to $\mathrm{ca} .10 \mathrm{~cm}$ in diameters).

Fig. 11 a) Sinkhole-like crater in the central depressed area (location in Fig. 3). b) Saline water spring. Note the high amount of iron precipitates due to its high content in the water.

Fig. $12 \delta^{18} \mathrm{O}$ vs. $\delta \mathrm{D}$ stable isotopes distribution in reservoir waters of the GograndagOkarem province and Boyadag anticline. Reservoir values are from Huseynov \& Guliyev (2004).

Fig. 13 Evolution sketch of the sediment remobilization in the Boyadag anticline (not to scale). a) The deep conduit of the mud volcano is responsible for the partial degassing of 
the reservoir, thus preventing important hydrocarbons accumulation. b) During a quiescence phase of the mud volcano the hydrocarbons migration increases the overpressure in the reservoir. c) The continuous hydrocarbons migration led the overpressure to above the hydrofracturing gradient and contributed to the sand remobilization. d) The progressive erosion exposed the sandstone intrusions, which are now responsible for the partial degassing of the reservoir.

Tab. 1 lons in the analysed brine. Concentrations are reported in ppm. Bdl: below detection level; - : not determined. a) from: Planke et al., 2003; b) from Lavrushin et al., 2005.

Tab. 2 Geochemistry of oils contained in the sediments near the gryphons. 




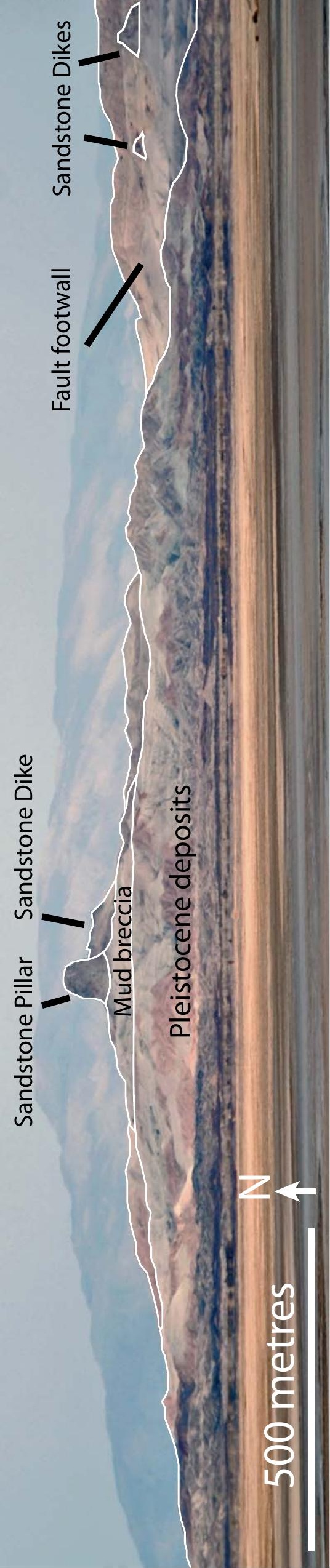




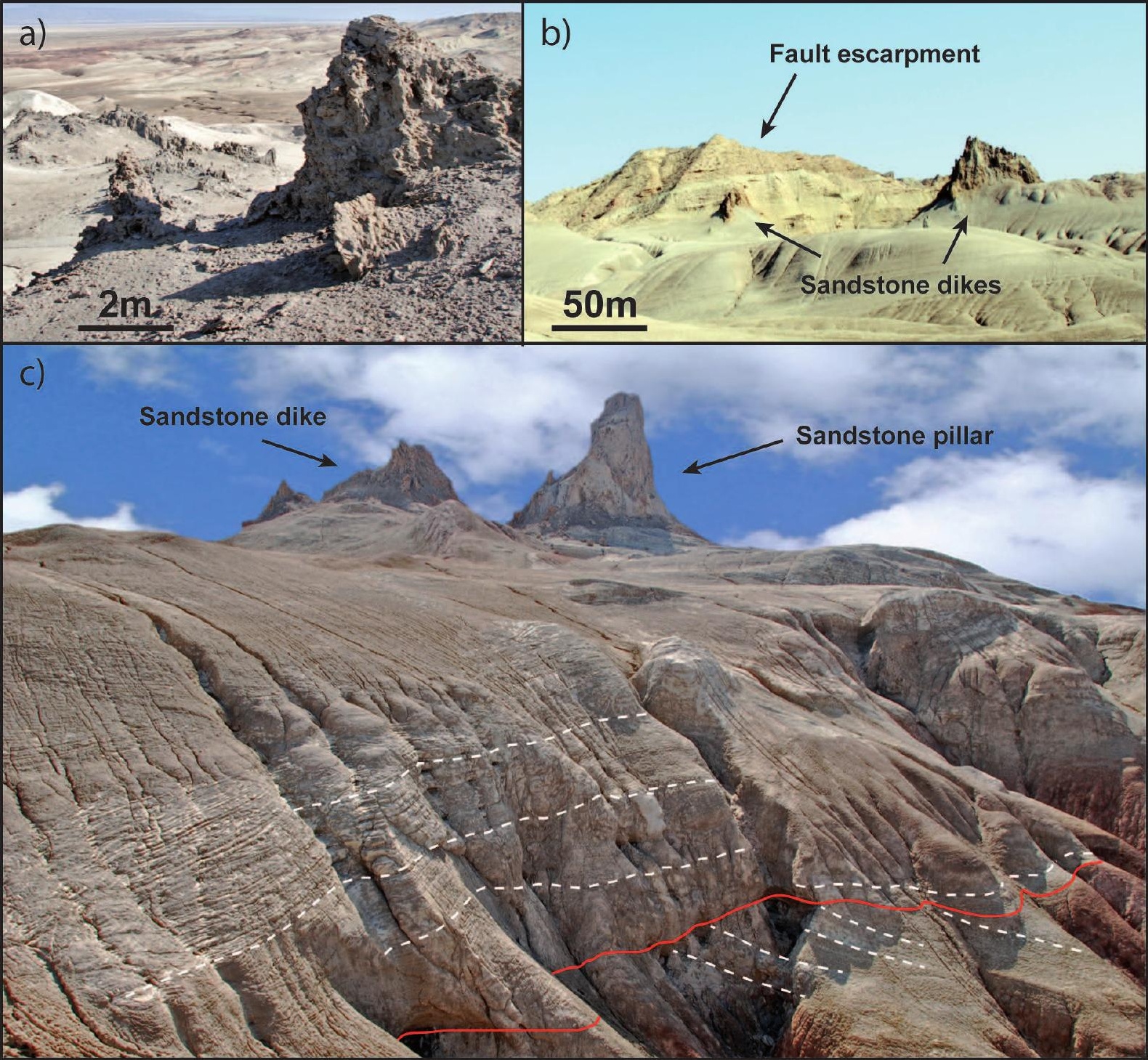




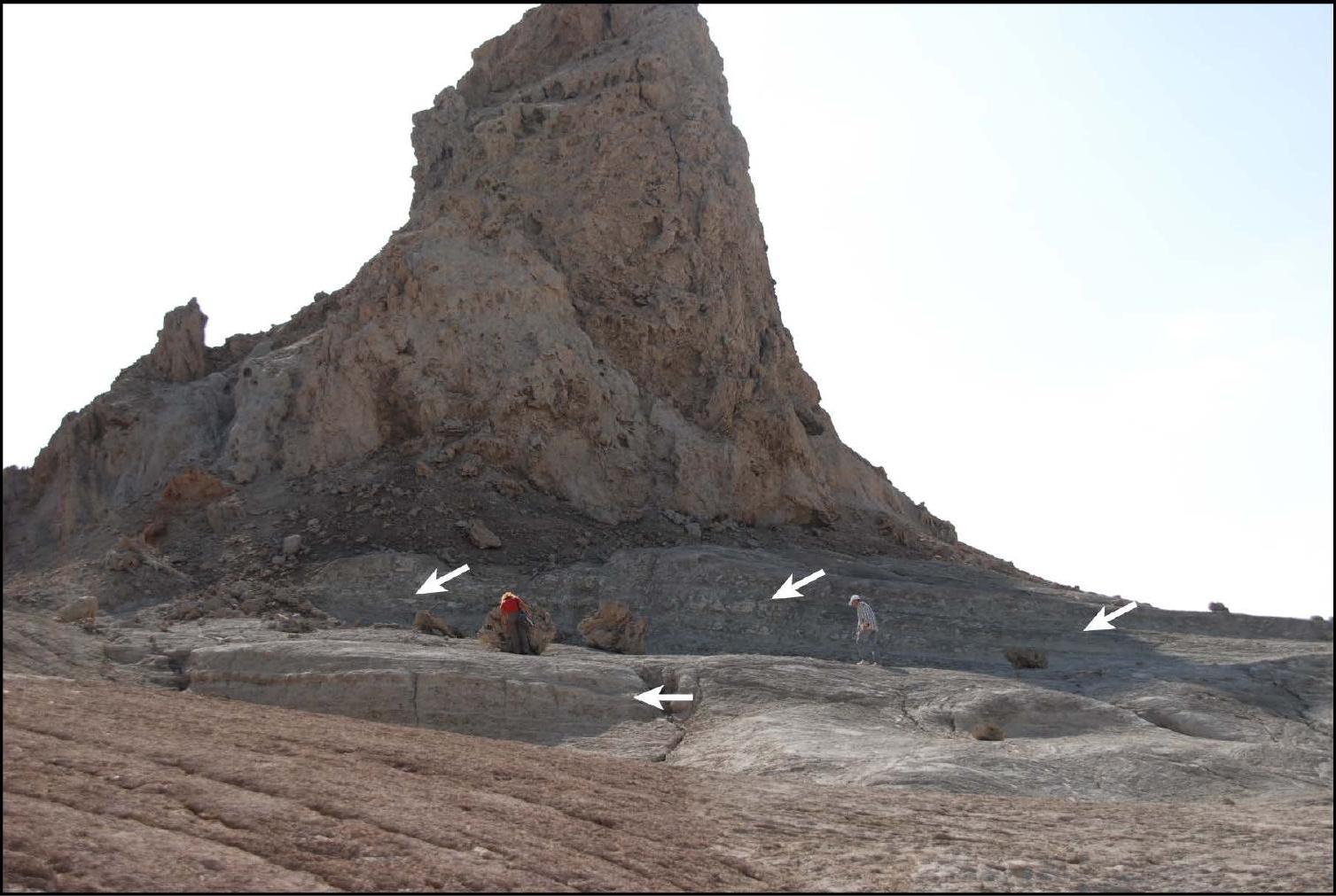


a)

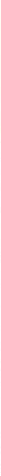

b)

c)

i. $]^{2} 7^{6}$

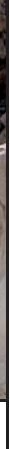

3

de. enthes

- Nas an

15.

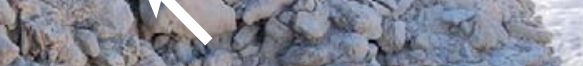

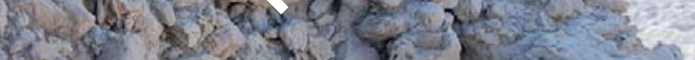

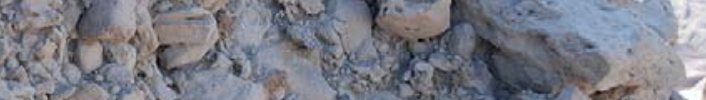

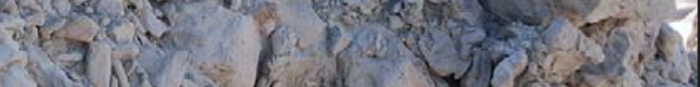
Ifisis lis of i) $\quad x-1$. 
a)

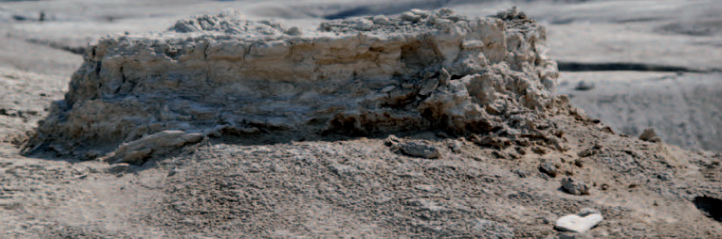

$20 \mathrm{~cm}$

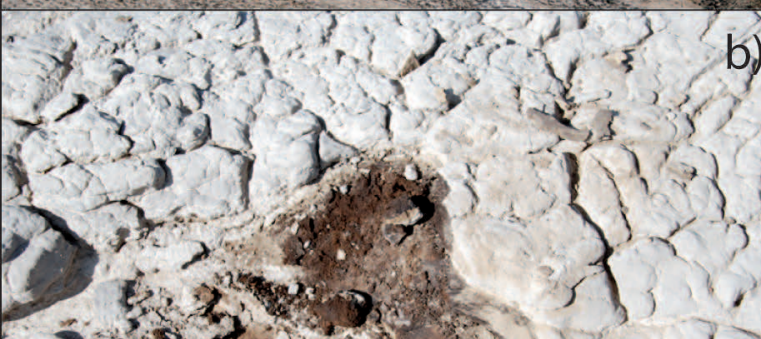

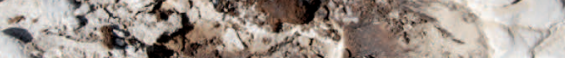

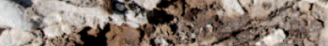

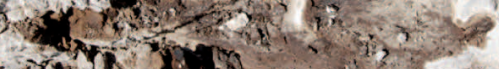

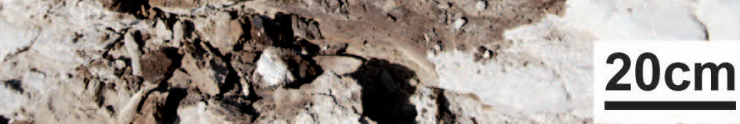

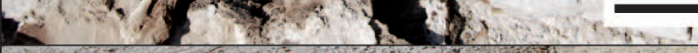

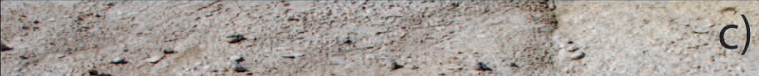

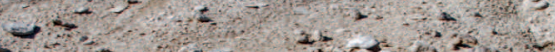

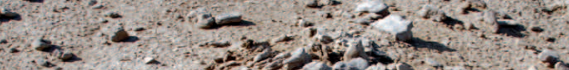

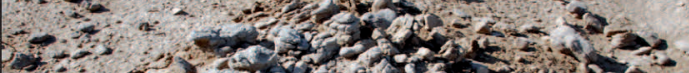

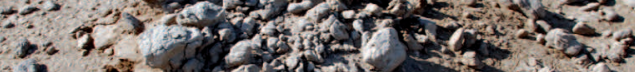

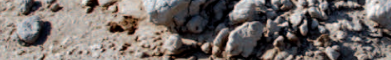

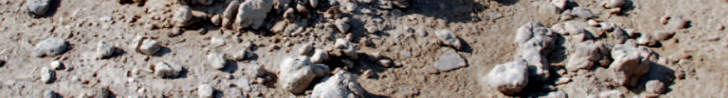

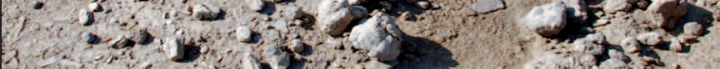

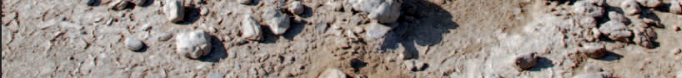

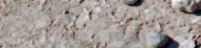

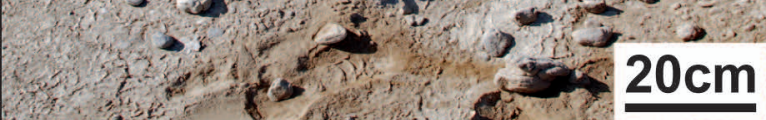


a)

b)

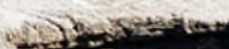

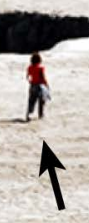

$50 \mathrm{~cm}$ 
- Boyadag

Sea Water

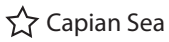

$\nabla$ Turkmenistan Oil Field Water

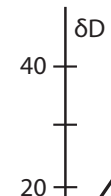

$\delta^{18} \mathrm{O}$

$-12$
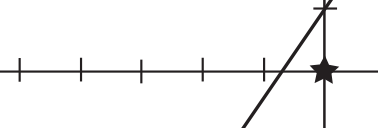

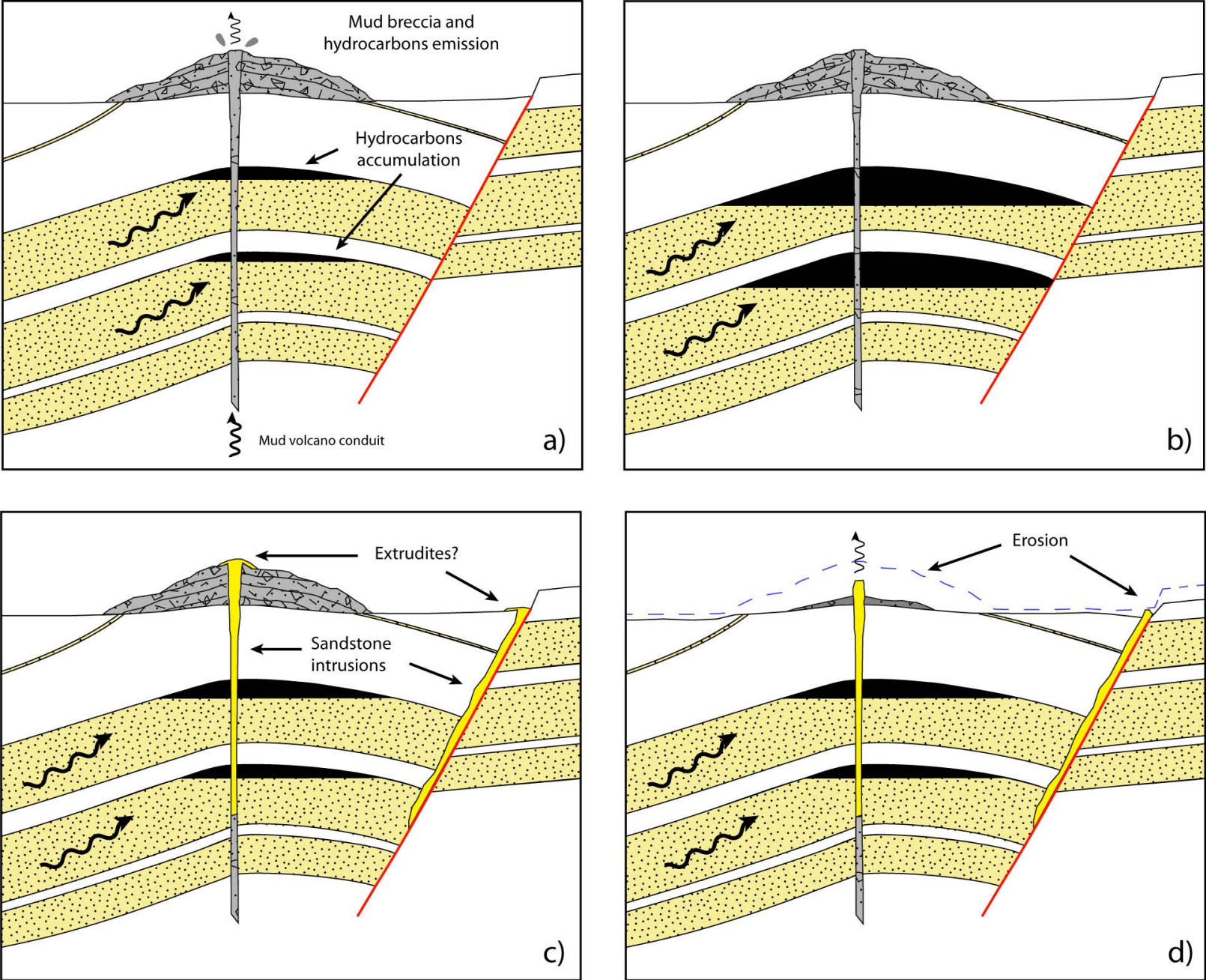


\begin{tabular}{|c|c|c|c|}
\hline & Boyadag & Sea Water & Caspian Sea ${ }^{a}$ \\
\hline Temperature $\left({ }^{\circ} \mathrm{C}\right)$ & 26 & & \\
\hline $\mathrm{pH}$ & 6.46 & & \\
\hline Eh $(m V)$ & -33.3 & & \\
\hline Measured Con. (mS/cm) & 200 & & \\
\hline $\mathrm{Cl}$ & 106350 & 19500 & 5650 \\
\hline $\mathrm{Na}$ & 55990 & 10770 & 3250 \\
\hline $\mathrm{Ca}$ & 9284 & 412 & 387 \\
\hline $\mathrm{Mg}$ & 899.8 & 1290 & 817 \\
\hline $\mathrm{HCO}_{3}$ & 12.2 & 140 & - \\
\hline $\mathrm{SO}_{4}$ & bdl & 2649 & 3167 \\
\hline $\mathrm{NH}_{4}$ & 35.6 & 0.07 & - \\
\hline I & 54 & 0.05 & - \\
\hline $\mathrm{Br}$ & 222 & 65 & 9 \\
\hline K & 779.4 & 380 & 90 \\
\hline B & 55.22 & 4.6 & - \\
\hline $\mathrm{Fe}$ & 4.531 & 0.02 & - \\
\hline $\mathrm{SiO}_{2}$ & 10.5 & 7 & - \\
\hline $\mathrm{H}_{2} \mathrm{~S}$ & 0.255 & 0 & - \\
\hline TDS & 173000 & 35220 & \\
\hline $\mathrm{Na} / \mathrm{Cl}$ & 0.5265 & 0.5523 & 0.5752 \\
\hline $\mathrm{Ca} / \mathrm{Cl}$ & 0.0873 & 0.0211 & 0.0685 \\
\hline $\mathrm{Mg} / \mathrm{Cl}$ & 0.0085 & 0.0662 & 0.1446 \\
\hline $\mathrm{HCO}_{3} / \mathrm{Cl}$ & 0.0001 & 0.0072 & - \\
\hline $\mathrm{SO}_{4} / \mathrm{Cl}$ & - & 0.1358 & 0.5605 \\
\hline $\mathrm{Br} / \mathrm{Cl}$ & 0.0021 & 0.0033 & 0.0016 \\
\hline $\mathrm{Mg} / \mathrm{Ca}$ & 0.0969 & 3.1311 & 2.1111 \\
\hline $\mathrm{K} / \mathrm{Cl}$ & 0.0073 & 0.0195 & 0.0159 \\
\hline $\mathrm{K} / \mathrm{Cl}$ & 0.0073 & 0.0195 & 0.0159 \\
\hline$\delta^{18} \mathrm{O}$ & 0.4 & 0 & $-4^{(\mathrm{b})}$ \\
\hline$\delta \mathrm{D}$ & -39.2 & 0 & $-23^{(b)}$ \\
\hline
\end{tabular}

Tab. 1 lons in the analysed brine. Concentrations are reported in ppm. Bdl: below detection level; : not determined. a) from: Planke et al., 2003; b) from Lavrushin et al., 2005. 


\begin{tabular}{l|c|c|} 
& Boyadag 1 & Boyadag 2 \\
\hline Oleanane/C30hop & 0.03 & 0.04 \\
Methylhopane & 4.64 & - \\
$\mathrm{R}_{\mathrm{c}}$ & 0.75 & 0.70 \\
Tri & 0.10 & 0.05 \\
Tet & 0.05 & 0.04 \\
Trit & 1.83 & 1.16 \\
C29Hop/C30Hop & 0.48 & 0.48 \\
C29ts/C30* & 4.96 & - \\
C30*/C30Hop & 0.03 & 0.04 \\
Diasterane ratio & 0.44 & 0.41 \\
\hline \multicolumn{2}{|c|}{ Organic Matter parameters } \\
C27/C29 sterane & 1.17 & 0.98 \\
C28/C29 sterane & 1.41 & 1.29 \\
\%C27 & 32.70 & 30.05 \\
\%C28 Maturity parameters & \\
\%C29 & 39.42 & 39.44 \\
Steranes/hopanes & 27.88 & 30.52 \\
\hline \multicolumn{2}{|c|}{0.17} & 0.19 \\
S/S+R terpane & 0.58 & 0.56 \\
S/S+R sterane & 0.43 & 0.4 \\
$\beta \beta /(\beta \beta+\alpha \alpha)$ sterane & 0.52 & 0.46 \\
S/S+R Homohopane & 0.59 & 0.58 \\
Ts/Ts+Tm & 0.76 & 0.76 \\
\hline
\end{tabular}

Tab. 2 Geochemistry of oils contained in the sediments near the gryphons. 